УДК 811.111'42

DOI 10.31654/2520-6966-2018-10f-91-246-255

\author{
A. M. Trybukhanchyk \\ PhD in Philology Associate Professor, Departament of Germanic Philology, \\ Nizhyn Gogol State University
}

\title{
Etymological aspects of a phraseosemantic field
}

The article is devoted to the analysis of etymological sources of a phraseosemantic field in English with the general meaning of man's material state in a historical perspective. Taking into account the information of etymological and explanatory dictionaries it was found that for the most part phraseological units of the field "richness-poverty" go down to traditions, customs, the way of life of English people. Besides, units of terminological origin occupy a considerable place. Among borrowed units the first in quantity are idiomatic expressions originating from the regional variants - American and Australian English.

Key words: phraseological unit, phraseosemantic field, native English, borrowed.

Recent years have seen an increase in the number of researches devoted to a systemic study of particular fragments of language structure. It is assumed that discrete facts and elements of language do not exist independently, but are connected by close relations which are based on certain principles. Systemic relationships are revealed at all language levels. This article deals with the level of phraseology.

Researchers have singled out a number of phraseosemantic fields. Numerous works have appeared which study paradigmatic, syntagmatic and stylistic characteristics of lexico-phraseological (or purely phraseological) fields united by a common semantic property - an idea or notion underlying the consolidation of phraseological and lexical units into a field. Researchers have concentrated their attention on various parts of lexical or lexico-phraseological system which verbalize certain essential mental concepts $[1 ; 3 ; 4 ; 5 ; 7 ; 9]$.

This article is an attempt to make an etymological diachronic analysis of a phraseosemantic field denoting the material state of man, which is represented as the field "richness-poverty". It includes phraseological units correlated with different parts of speech of nominating and nominatingcommunicative nature united by the generic notion "richness-poverty". The singling out of the PhUs belonging to this field becomes possible due to a complex logic-linguistic methodology, taking into account the data of 
ideographic and explanatory dictionaries. At the initial stage we single out the basic identifier of the field - a lexical unit corresponding to the content of the semantic field. In the given case these are the lexical units $\mathrm{RICH}$ and POOR. But as we analyze all aspects of this notion, i.e. not only the attribute, but also the substance, state and process, so the range of basic identifiers will expand and include units belonging to different parts of speech; these units or their combinations will correlate with phraseological units filling in the field "richness-poverty". So, the inventory of basic identifiers looks like the following:

RICHNESS-RICH-RICHLY-BE RICH-ENRICH

POVERTY-POOR-POORLY-BE POOR-MAKE POOR

Next, using explanatory dictionaries, a semantic invariant for each member of the above paradigm was determined.

For instance, for the notion $\mathrm{RICH}$ a complex of indicators "having large possessions, much money, abundant means; wealthy" turned out to be invariant, for the notion "POOR" - "having little or no necessaries of life, money, means of support," etc. The singled out set of invariant features was taken as the semantic invariant for PhUs correlated in meaning with basic identifiers.

At the subsequent stage we used one of the most authoritative ideographic dictionaries Roget's College Thesaurus, making it possible to determine the volume of the notions "richness" and "poverty" in English. It was confirmed with its help that the idea of poverty embraces such manifestations of it as RUIN, STRIPPING, BEGGARY, BANKRUPTCY, STARVATION [16]. For this reason we deemed it possible to include PhUs having the semantic invariant correlating them with such aspects of poverty. Thus, the main criterion for including a $\mathrm{PhU}$ into the phraseosemantic field under study was the availability in its meaning of certain elements of the semantic invariant - a linguistic correlation of the notion "richness-poverty", for instance; a King's ransom - a very great, perhaps incalculable, sum of money; on hard tack - the state of being poor, without money. Componential analysis made it possible to find out PhUs in whose meaning the relevant features exist implicitly, e.g. a coin cove $\rightarrow$ a man in funds $\rightarrow$ a man having much money, etc.

The methodology described above enabled us to single out 421 PhUs of nominating and nominating-communicative character. While making a sociolinguistic analysis of set expressions referring to the investigated phraseosemantic field it is important to determine their origin. This task becomes possible taking into account the information contained in various types of dictionaries and the classification scheme suggested by A. V. Kunin [2]. 
Group 1. Native English phraselogical units of non-terminological origin.

1. The first place in quantitative terms (241, i.e. $57,3 \%$ ) belongs to the subgroup of PhUs reflecting in their semantics and going down to different traditions, customs and the way of life of native English speakers. It is common knowledge that an impetus to a PhU emergence can be various extralinguistic factors and a PhU appearance is relatively accidental, as it is impossible to fortell at once if a certain word combination will turn into a set phrase and which meaning exactly will be reintegrated and become a PhU [6, p. 45].The sources of this phraseological group lie in diverse life situations. The key word around which a set expression is formed often belongs to the most widely used words, mostly nouns.

Listed below are a few examples included in this subgroup. As a $\mathrm{PhU}$ peculiarity is its frequent coincidence in form with a free word combination (in other words, we deal with its genetic source [6]), it is relatively easy to determine it. The origin of many PhUs is associated with facts taken from everyday reality. For instance, observations of beggars' miserable existence in the slums led to the appearance of the figurative expression be born in the gutter, which later came to be used in a generalized meaning "to be born in poverty or in a poor family". The free word combination a long stocking began to be associated with the custom of putting one's money into a stocking for safety, and because the custom was widely spread, by means of a metonynic transference, it came to signify a large sum of money in general - "a store of money" [OED]. The associative nature of human thinking led to the creation of other PhUs belonging to this subgroup.

2. Among native English PhUs of non-terminological origin we have identified 24 units $(9,5 \%)$ connected with English realia. Thus, the then existing phrase three outs: out of pocket, out of elbow, out of credit made it possible to form the PhU a gentleman of three outs $\left(18^{\text {th }}-21^{\text {st }} \mathrm{c}\right.$. $)-$ "a gentleman without money, clothes and good name". The PhU a gentleman ranker $\left(19^{\text {th }}-20^{\text {th }} \mathrm{c}\right.$.) is connected with the tradition for bankrupt nobleman to serve as common soldiers: "a broken gentleman who serves in the ranks" [DS]. Also a close connection with realia is felt in such PhUs as go due north - "to go bankrupt" (in the $19^{\text {th }} \mathrm{c}$. there was a prison for debtors and bankrupt people in the north of London) and not a rap - "without any money" (after the false coin worth half a penny in circulation in Ireland in the $18^{\text {th }} \mathrm{c}$.).

3. 5 units in the phraseosemantic field $(2,1 \%)$ are connected with beliefs and superstitions existing among people. For instance, the PhU Quees Street $\left(19^{\text {th }}-21^{\text {st }}\right.$ c. $)$ is based on the belief that the poor inhabit 
such a street and means "poverty". The idea that poor people can fall so low as to steal food lying on tombstones became the basis of the PhU carry off meat from the graves $\left(19^{\text {th }}-20^{\text {th }} \mathrm{C}\right.$.) - "to be so poor as to descend to robbing the tombs of offerings" [BDPF].

4. $14 \mathrm{PhUs}(15,8 \%)$ go back to the facts of English history. Six of them are connected with the life of indigent people in workhouses which where set up all over the country to provide the poor with material assistance. Poor people who were constantly admitted to a workhouse and later leaving it, were called ins and outs. There existed whole families permanent inhabitants of such institutions, hence the phraseological unit an in and out family. Also there were special schools supported by charitable donations (charity schools); children who studied there were called poor children. The PhUs mentioned refer to the $19^{\text {th }}-20^{\text {th }}$ centuries.

Group II. Native English PhUs of terminological origin.

71 phraseological units in this field (16,9\% of all PhUs) can be traced back to various professional spheres of activity. Connection of the phraseosemantic field with monetary relationships is proved by availability of 19 units $(26,8 \%)$ going down to business and commerce. For instance, a considerable bank deposit, written down in "black and white", resulted in the emergence of the PhU be in the black $\left(19^{\text {th }}-20^{\text {th }} \mathrm{c}\right.$. $)$ - "to do profitable business, to obtain profit". On the other hand, the figures signifying debt sums, were put down in red ink, consequently, the appearance of the idiom be in the red. The stock market slang gave rise to such PhUs as strike a docket $\left(19^{\text {th }} \mathrm{c}\right.$.) - "to cause a man to become bankrupt" [DS], a lame duck $\left(18^{\text {th }}-21^{\text {st }} c\right.$. $)$ - "an insolvent stock broker, a profiteer."

6. 16 units in the phraseosemantic field "richness-poverty" have their etymological roots in marine terminology. It is well-known what an important role the sea has had in the lives of English people. The resultant sea-related expressions were later reinterpreted and came to be included into different phraseosemantic fields [8]. Thus, difficulties in sea-faring caused by high and low tides became the reason for the appearance of the PhU be at low water/tide $\left(18^{\text {th }}-21^{\text {st }} \mathrm{c}\right.$.), meaning "to be without money." Many idioms are connected with ship movement and sea manoeuvres, for example be thrown on one's beam end - "to be reduced to one's last resources" [DEP]. It is noteworthy that the semantic structure of phraseological sea-related idioms belonging to the subfield POVERTY often includes the semantic component "catastrophy", for example run aground $\left(19^{\text {th }}-21^{\text {st }} \mathrm{c}\right.$.) or go on the rocks $\left(20^{\text {th }}-21^{\text {st }} \mathrm{c}\right.$. $)$, both of which mean "to become bankrupt". It is possible to assert that due to their expressiveness and vivid imagery such phrases turn into phraseological ones faster and enrich the idiomatic vocabulary. 
7. Some other professionally-related sources of this phraseosemantic field include: a) gambling (2 units), e.g. break the bank $\left(17^{\text {th }}-21^{\text {st }} c\right.$. $)-$ to win all the money in a game of chance [LDEl]; b) horse racing (5 units), e.g. come a cropper $\left(19^{\text {th }}-20^{\text {th }}\right.$ c.) - "to become bankrupt"; up in the stirrups $\left(18^{\text {th }}-19^{\text {th }}\right.$ c.) - "having plenty of money"[DS];c) the times of the "gold rush" and search for natural resources, e.g strike gold $\left(19^{\text {th }}-20^{\text {th }} \mathrm{c}\right.$.) "to discover a rich source of wealth, information, happiness, etc."[OED]; a gold mine $\left(19^{\text {th }}-20^{\text {th }} \mathrm{c}\right.$.) - "a mine producing gold, a source of rich profit"[Chambers].

Group III. Native English PhUs of literary origin.

8. Shakespeare's expressions in this phraseosemantic field are rather scarce (3 units): curled darlings - "rich young loafers" ("Othello"); eat smb out of house and home - "to make a person poor by living at his expense" ("King Henry IV"); live on the alms basket - "to live on charity".

9. The same number of PhUs (3units) has been borrowed from other literary sources. Two of them were created by Charles Dickens: go to the demnition bow-vows $\left(19^{\text {th }}-20^{\text {th }} \mathrm{C}\right.$. $)$ - "to become ruined, bankrupt", and a bag of bones - "an emaciated person" ("Oliver Twist"). The wellknown PhU be born with a silver spoon in one's mouth - "to be born of wealthy parents" [LDEl] which came into use at the end of the $18^{\text {th }}$ century, has has its literary predecessor - the phrase be born with a penny in one's mouth, coined by J.Clark in 1639.

IV. Borrowed phraseological units.

10. The Bible is known to be the most important literary source which has enriched the phraseological fund of the English language. As L.P.Smith points out, "the number of biblical phrases and expressions in English is so great that it would be quite a difficult task to collect and enumerate them" [8, p.111]. In the phraseosemantic field "richness poverty" 11units have been singled out. The corresponding examples are: as poor as Job $\left(14^{\text {th }}-20^{\text {th }}\right.$ c.) - "very poor", the fleshpots of Egypt $\left(18^{\text {th }}-20^{\text {th }} \mathrm{c}\right.$. $)$ - "material possessions", the mammon of unrighteousness $\left(14^{\text {th }}-20^{\text {th }}\right.$ c. $)-$ "wealth" [BDPF].

11. 5 units in this phraseosemantic field $(4,8 \%)$ go down to ancient mythology, history and literature. Here belong such PhUs as: as rich as Croesus $\left(16^{\mathrm{h}}-21^{\text {st }} \mathrm{c}\right.$.) - "very wealthy (from the name of a king in Lydia in ancient times)" [LDEI] and its synonym as rich as Philip of Macedon, as well as the goose that lays the golden eggs $\left(19^{\text {th }}-21^{\text {st }} \mathrm{C}\right.$. $)$ - "a source of enrichment" (from an Aesop's fable) and others.

12. The French language has enriched the phraseosemantic field under study with 9 units. Here we find such idioms as pull the devil by the tail $\left(19^{\text {th }}-20^{\text {th }}\right.$ c.) - "to be in difficulties or straits" [OED] (Fr. tirer le 
diable par la queue); the new $(l y)$ rich $\left(19^{\text {th }}-21^{\text {st }}\right.$ c.) - "the people who became rich suddenly" (Fr. nouveaux riches) and others.

13. A considerable part among borrowed PhUs (78 units, i.e. $75,8 \%$ ) is made up of borrowings from regional variants - American, Australian, New Zealand. They can reflect local realia, as a poor white "a poverty - stricken white laborer or farmer in the southern US" [NWD], the codfish aristocracy $\left(19^{\text {th }}\right.$ c.) - the social aristocracy of regional belonging, e.g. flat broke $\left(19^{\text {th }}-21^{\text {st }} \mathrm{c}\right.$. $)$ - "penniless, ruined" [DS]; be on the hog $\left(20^{\text {th }} \mathrm{C}\right.$.) - "to go bankrupt". Most of the regional borrowings in this phraseosemantic field can be traced to the $19^{\text {th }}-20^{\text {th }}$ centuries.

The quantitative distribution of PhUs according to their sources of origin can be illustrated by the following table.

Table 1

\begin{tabular}{|c|c|c|c|c|c|c|c|c|c|c|c|c|c|}
\hline & \multicolumn{9}{|c|}{ Native English } & \multicolumn{4}{|c|}{ Borrowed } \\
\hline & \multicolumn{4}{|c|}{$\begin{array}{c}\text { Non-Terminological } \\
\text { origin }\end{array}$} & \multicolumn{3}{|c|}{$\begin{array}{c}\text { Terminological } \\
\text { origin }\end{array}$} & \multicolumn{2}{|c|}{\begin{tabular}{|l|} 
Literary \\
sources \\
\end{tabular}} & & & & \\
\hline 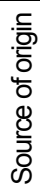 & 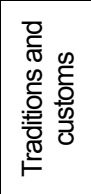 & 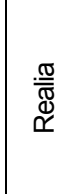 & $\frac{\stackrel{\omega}{\underline{\omega}}}{\stackrel{\frac{\omega}{\Phi}}{\infty}}$ & 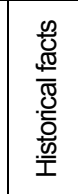 & 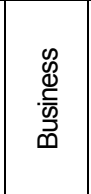 & 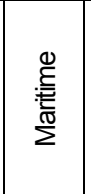 & $\begin{array}{l}\frac{\mathscr{\rho}}{\mathbb{E}} \\
\bar{\delta}\end{array}$ & 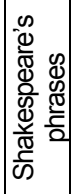 & $\begin{array}{l}\frac{\infty}{0} \\
\frac{D}{0}\end{array}$ & $\begin{array}{l}\frac{\overline{\widetilde{O}}}{\overline{\underline{0}}} \\
\overline{\overline{0}}\end{array}$ & 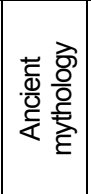 & 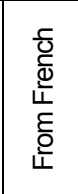 & 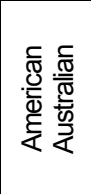 \\
\hline $\begin{array}{l}\bar{\Phi} \\
\text { है } \\
\text { है }\end{array}$ & 199 & 23 & 5 & 14 & 19 & 16 & 36 & 3 & 3 & 11 & 5 & 9 & 78 \\
\hline$\%$ & $82,6 \%$ & $9,5 \%$ & $2,1 \%$ & $5,8 \%$ & $26,8 \%$ & $21,5 \%$ & $50,7 \%$ & $50 \%$ & $50 \%$ & $10,70 \%$ & $4,80 \%$ & $8,70 \%$ & $75,80 \%$ \\
\hline $\begin{array}{l}\overline{\bar{\sigma}} \\
\frac{\overline{0}}{\bar{d}} \\
\text { ठ }\end{array}$ & \multicolumn{4}{|c|}{$241(57,3 \%)$} & \multicolumn{3}{|c|}{$71(16,9 \%)$} & \multicolumn{2}{|c|}{$6(1,4 \%)$} & \multicolumn{4}{|c|}{$103(24,4 \%)$} \\
\hline 要 & \multicolumn{13}{|c|}{421} \\
\hline
\end{tabular}

The statistic data concerning the distribution of the units included in the phraseosemantic field "richness-poverty" according to etymological sources show that the overwhelming majority of set expressions having phraseological character is made up of phrases having preternaturally English nature and have originated mostly from free word combinations (318 units, i.e 75,4 \%). Among native English PhUs of terminological character the majority (19 units, i.e $26,8 \%$ ) go down to the spheres of trade, banking, stock exchange, monetary circulation, which is quite natural for a phraseosemantic field characterizing economic processes. It is possible to surmise that in other phraseosemantic fields the proportion of units from terminological sources will be different depending on the 
field's specificity. It is also noteworthy that the second place in terms of quantity (16 units, i.e 22,5\%) among the terminological ones is occupied by PhUs whose prototypes were phrases from nautical lexicon. It should be noted that many of them reflect extreme situations and are regarded as vivid metaphorically reinterpreted figurative phrases. Numerous examples from other professional sources (36, i.e $50,7 \%$ ) testify to the productivity of various spheres of human activity for phraseology enrichment.

For the phraseosemantic field "richness-poverty" the connection with social-economic processes taking place in various periods of English people's history is the most conspicuous in the subgroup of set phrases having native English origin. According to our research, the most considerable increase of nominating and nominating-communicative phraseology is observed from the $16^{\text {th }}$ to the $20^{\text {th }}$ century, which is indirectly connected with the development of socio-economic relationships in society, formation of commodity-monetary relations and growth of diverse trades, expansion of colonial rule as well as with the fact that phraseological units which had been accumulating in people's speech over many centuries, found their reflection in rapidly developing fiction. The formation of the English national language was connected with its democratization which resulted in a wider representation of people's language in literature, the flourishing of various styles and genres, all of which was alien to the majority of literary works of the $11^{\text {th }}-14^{\text {th }}$ centuries.

Borrowings from literary sources also took place mostly in the middle-English and early modern English periods. Biblical PhUs, which undoubtedly existed in the language before, began to be registered from the $15^{\text {th }}$ century, and their greatest quantity is observed in the $16^{\text {th }}$ and $19^{\text {th }}$ centuries. Shakespeare's expressions come into use beginning with the $16^{\text {th }}-17^{\text {th }}$ centuries, though it should be noted that at the moment of their appearance they did not possess a phraseological character yet. They turned into phraseological units later, when they were adopted by the people and began to be used by other writers.

Regional borrowings in this phraseosemantic field mostly refer to the $19^{\text {th }}-20^{\text {th }}$ centuries, as it was at this period that intensive development of territories in America and Australia was taking place, and the new language communities' life gave birth to a diversity of image-bearing phrases reflecting both national specificity and customs, temper, various life situations of new peoples. Here are a few characteristic examples: a butter-and-egg man (Am.) - 1) a rich man spending money like water, 2) a businessman financing theater productions for a profitable purpose; be born on the wrong side of the tracks (Am.) - "to be born in a poor family, come from lower classes" (the component "tracks" here means the 
railroad on the outskirts of some American townships, beyond which the town slums are situated); a coiny cove (Austr.) - "a man in funds" [DS]; a sugar daddy (Am.) - "a rich elderly admirer". Borrowings from French and other languages, despite great influence of the former on the development of English, turned out to be insignificant. This fact once again proves the maxim that the overwhelming part of the English phraseological fund has its national specific character.

Communicative phraseological units reflect historical events by conveying people's emotionally-evaluative attitude to them. It is not accidental therefore that a considerable number of proverbs about richness and poverty are traced back to the $14^{\text {th }}-16^{\text {th }}$ centuries, when the phenomenon of mass poverty among common people and concentration of wealth in the hands of the ruling classes was not an exception, but had a nationwide character. Besides, one more circumstance should be pointed out. It is well-known that in the majority of cases PhUs pass through a long period of formation, so the date of the first fixation of a $\mathrm{PhU}$ in a work of fiction is not the exact date of its appearance in the language. The use of a $\mathrm{PhU}$ in belles-lettres works (except for PhUs of literary origin) as a rule is not its first use and only testifies to the fact that the PhU in question appeared in the language not later than the date indicated. For this reason the life of a PhU should be characterised in terms of centuries, not forgetting the relative aspect of temporal parameters of phraseological units.

\section{References}

1. Вальчук Г. В. Мовне втілення концепту "Європейська інтеграція": семантико-когнітивний аспект: авторефр. дис. ... канд. філол. наук: 10.02.04. Київ, 2003. 20 с.

2. Кунин А. В. Курс фразеологии современного английского языка. Дубна: Феникс, 2005. 488 с.

3. Луньова Т. В. Лексикалізований концепт ГАРМОНІЯ в сучасній англійській мові: структура і комбінаторика: дис. ... канд. фрілол. наук: 10.02.04. Київ, 2006. 348 с.

4. Мазирко Д. А. Англоязычное фразеосемантическое поле отношений личности. Вестник РУДН, Серия "Вопросы образования: языки и специальность". Москва, 2009. № 2. С. 59-64.

5. Мірошніченко І. М. Фразеосемантичне поле "праця / неробство" в польській мові: авторефр. дис. ... канд. фрілол. наук: 10.02.03. Київ, 2010. 20 с.

6. Назарян А. Г. Фразеология современного французского языка: учеб. 2-е изд. М.: Высш. шк., 1987. 288 с.

7. Прохорова А. П. Фразеосемантическое поле "говорение": лингвопрагматический аспект (на материале русского и французского языков): дис... канд.филол. наук: 10.02.19. Ростов-на-Дону, 2017. 193 с.

8. Смит Л. П. Фразеология английского языка. Москва: Наука, 1995. $183 \mathrm{c}$. 
9. Фещенко Ю. І. Ідіоматичний простір "homo socialis" у сучасній англійській мові: лінгвокогнітивний та комунікативно-функціональний аспекти: автореф. дис. ... канд. фрілол. наук: 10.02.04. Київ, 2007. 20 с.

10. BDPF: Brewer E.G.Brewer's Dictionary of Phrase and Fable. - 19th ed. L.: Chamber's Harap, 2013. 990 p.

11. Chambers: Chambers W., Chambers R. Chambers $20^{\text {th }}$ Century Dictionary of the English Language. Rev.Ed. Edinburg: Chambers, 1977. 1652 p.

12. DEP: Hyamson A. M. A Dictionary of English Phrases. Detroit: Gale Research Co., 1970. 365 p.

13. DS: Partridge E. A. The New Partridge Dictionary of Slang and Unconventional English. - 8th Ed. by T. Dowzall and T. Victor. L.: Routledge and Kegan Paul, 2013. 2485 p.

14. LDEl: Longman Dictionary of English Idioms/ed.director. Edinburg Gate, Harlow: Longman Group UKLimited, 1996. 387 p.

15. NWD: New Webster's Dictionary of the English language/ Executive ed.

E.G. Finnegan. Access mode: URL: https://www.merriam-webster.com

16. Roget's II Electronic Thesaurus. - Microsoft Bookshelf CD-ROM Reference Library. Wearness, 1993.

17. OED: Oxford English Dictionary Online. URL: http://www.oed.com/

\section{References}

1. Valchuk G. V. Movne vtllennya kontseptu "Evropeyska Integratslya": semantiko-kognltivniy aspekt: avtoref. dis... kand. fllol. nauk: spets. 10.02.04. KiYiv, 2003. $20 \mathrm{~s}$.

2. Kunin A. V. Kurs frazeologii sovremennogo angliyskogo yazyika. Dubna : Feniks, 2005. $488 \mathrm{~s}$.

3. Lunova T.V. Leksikallzovaniy kontsept GARMONIYa $v$ suchasnly angllyskly movl: struktura I komblnatorika: dis... kand. fllol. nauk: spets. 10.02.04. KiYiv, 2006. 348 s.

4. Mazirko D. A. Angloyazyichnoe frazeosemanticheskoe pole otnoshe-niy lichnosti. Vestnik RUDN, seriya "Voprosyi obrazovaniya: yazyiki i spetsialnost". \# 2. Moskva, 2009. S. 59-64.

5. Mlroshnlchenko I. M. Frazeosemantichne pole "pratsya/ nerobstvo" $v$ polıskly movl: avtoref. dis... kand. fllol. nauk: spets. 10.02.03. KiYiv, 2010. 20 s.

6. Nazaryan A. G. Frazeologiya sovremennogo frantsuzskogo yazyika: Ucheb. 2-e izd. M. Vyissh. shk., 1987. 288 s.

7. Prohorova A. P. Frazeosemanticheskoe pole "govorenie": lingvopragmaticheskiy aspekt (na materiale russkogo i frantsuzskogo yazyikov): dis... kand.filol.nauk: spets. 10.02.19. Rostov-na-Donu, 2017. 193s.

8. Smit L. P. Frazeologiya angliyskogo yazyika. Moskva, Nauka, 1995. $183 \mathrm{~s}$.

9. Feschenko Yu. I. Idlomatichniy prostlr "homo socialis" u suchasnly angllyskly movl: IIngvokognltivniy ta komunlkativno-funktslonalniy aspekti: avtoref. dis... kand. fllol. nauk: spets. 10.02.04. KiYiv, 2007. 20 s.BDPF: Brewer E.G.Brewer's Dictionary of Phrase and Fable. - 19th ed. L.: Chamber's Harap, 2013. 990 p. 
10. Chambers: Chambers W., Chambers R.Chambers $20^{\text {th }}$ Century Dictionary of the English Language. Rev.Ed. Edinburg: Chambers, 1977. 1652 p.

11. DEP: Hyamson A. M. A Dictionary of English Phrases. Detroit: Gale Research Co., 1970. 365 p.

12. DS: Partridge E.A. The New Partridge Dictionary of Slang and Unconventional English. -8 th Ed. by T. Dowzall and T. Victor. L.: Routledge and Kegan Paul, 2013. - 2485 p.

13. LDEl: Longman Dictionary of English Idioms/ed.director. Edinburg Gate, Harlow: Longman Group UKLimited, 1996. 387 p.

14. NWD: New Webster's Dictionary of the English language/ Executive ed. E.G. Finnegan. Access mode: URL: https://www.merriam-webster.com

15. Roget's II Electronic Thesaurus [Electronic resource]. - Microsoft Bookshelf CD-ROM Reference Library. - Wearness, 1993.

16. OED: Oxford English Dictionary Online [Electronic resource] URL: http://www.oed.com/

\section{А. М. Трибуханчик \\ кандидат філологічних наук, доцент кафедри германської фрілології Ніжинського державного університету імені Миколи Гоголя}

\section{Етимологічні аспекти фразеосемантичного поля}

Статтю присвячено аналізу джерел походження одного фрразеосемантичного поля в англійській мові зі значенням матеріального стану людини в історичній перспективі. На основі вивчення інформації етимологічних і тлумачних словників встановлено, що в основному фрразеологізми семантичного поля "багатство-бідність" сягають традицій, звичаїв, способу життя англійського народу. Також вагоме місце займають фразеологізми термінологічного походження. Серед запозичених одиниць переважають фрразеологізми, що прибули з регіональних варіантів - американізми й австралізми.

Ключові слова: фрразеологізм, фрразеосемантичне поле, споконвічно англійські, запозичені.

\section{А. М. Трибуханчик}

кандидат филологических наук, доцент кафедры германской фрилологии Нежинского государственного университета имени Николая Гоголя

\section{Этимологические аспекты фразеосемантичного поля}

Статья посвящена анализу источников происхождения одного фрразеосемантического поля в английском языке со значением материального положения человека в историческом ракурсе. На основе изучения информации этимологических и толковых словарей установлено, что в основном фрразеологизмы семантического поля "богатство-бедность" уходят корнями в традиции, обычаи, образ жизни английского народа. Также весомое место занимают фразеологизмы терминологического происхождения. Среди заимствованных единии преобладают фрразеологизмы, пришедшие из региональных вариантов - американизмы и австрализмы.

Ключевые слова: фрразеологизм, фрразеосемантическое поле, исконно английские, заимствованные. 